\title{
Analysis of Product Innovation Performances in Terms of Competitive Strategies of Companies in Production Sector Under the Influence of Technology Orientation
}

\author{
Mehmet Celikyay $^{1}$, Zafer Adiguzel ${ }^{2 *}$ \\ ${ }^{1}$ Gebze Technical University, Social Sciences Institute, Kocaeli, Turkey \\ ${ }^{2}$ Istanbul Medipol University, Medipol Business School, Istanbul, Turkey
}

Keywords:

Technology Orientation, Competitive Strategies, Cost

Leadership Strategies,

Differentiation Strategies,

Product Innovation

\section{Received}

30 December 2019

Received in revised form

01 March 2020

Accepted

06 April 2020

Correspondence:

zadiguzel@medipol.edu.tr

\begin{abstract}
Innovation is considered to be one of the most important research areas in the field of science and technology policies in recent years and it is seen as the main driving force of economic growth and welfare increase. In today's competitive global economy, a firm's product innovation capability determines its competitiveness and effectiveness in national or international production and trade networks. Companies that follow a cost leadership strategy can mainly compete at a lower price, which they can do by reducing their costs through efficient resource/production/distribution and scale economies The sustainability of the companies in this competitive environment with sustainable profitability depends on the determination of the competitive strategies to be put into practice and the strategy they implement in the most rational way. In this study, 383 white collar (engineer) employees were surveyed. The factor analysis (explanatory and confirmatory) and reliability analysis of the scales was conducted using SPSS 25 and AMOS Program. The correlation and regression analysis, and sobel and Hayes process tests were performed to examine the effect of mediator variable. The results showed that there is a statistically positive and meaningful relationship between technology orientation and product innovation. In addition, it was found that the cost leadership and differentiation strategies have a mediation effect in this relationship.
\end{abstract}


Today, due to the phenomenon of globalization, it is much more difficult for enterprises under intense and regional competitions to cope with their competitors and achieve the expected performances. Although companies operating in the same environment or sector face the same challenges, they are unable to respond to the environment in the same way and their answers to their competitors differ depending on technological infrastructure of the companies. Technology determines the competitiveness of an organization, while orientation determines the direction in which an organization can compete; general or persistent thinking, tendency or direction of interest. The way to succeed in competition is through strategy. The strategy is seen as the first way to increase profitability, gain financial performance or competitive advantage, and understand the actions taken by firms (Masa'deh, Al-Henzab, Tarhini, \& Obeidat, 2018). Analysis of strategy creation and implementation processes has been the basis for strategic management and business policy efforts for many years (Bulut, Alpkan, \& Y1lmaz, 2009). Organizations are required to continuously produce new products and services in order to gain a competitive advantage over their competitors in environmental conditions. In this respect, innovation recognized as an important strategy that must be implemented for businesses located in a competitive market. It has become a necessity for organizations to gain competitive advantages in order to perform better than their competitors. To this end, Porter (1985) refers to the low-cost leadership and differentiation strategy as the two key competitive advantage strategies. The cost leadership is to produce products and services at a lower cost than competitors and to reach a wider customer segment, while the differentiation strategy is unique or different products and services to be unique in the market and be able to offer these services in the market. Some related studies indicate that the differentiation strategy provides higher financial performance in the long run and some studies show the relationship between innovation and innovation (Zehir, Can, \& Karaboga, 2015). For this reason, companies that tend to survive in the intense competitive environment in most of the sectors in general need to attach importance to technology orientation by considering certain competitive strategies in order to present new and different products, services and processes that cannot be easily imitated by others. In this respect, cost leadership and differentiation strategies, technology orientation and product innovation are closely related. This study investigates the relationships between technology orientation, cost leadership, differentiation strategies, and product innovation. The competitive strategies appear to be a mediation role in the relationship between technology orientation and product innovation.

\section{Technology Orientation}

Technology orientation focuses on product technology that strongly affects the type of products, processes management and materials produced. Technology orientation of a business unit follows (1) technological stance which refers to the leadership role of that business unit as a technology user or developer, (2) new product development that defines the new product ratio of the business unit and reflects the importance of $R \& D$ in the operational strategy, and (3) automation and process innovation that means the use of the latest technology in the transformation process, the allocation of capital for new equipment and the level of automation in the transformation process (Williams, D'Souza, Rosenfeldt, \& Kassaee, 1995). Technology orientation is can be defined that companies focus on R \& D 
and include new technologies in product development. Technology orientation can also be defined as companies' openness to new ideas and the tendency to adopt new technology during the development of products. When businesses implement new ideas, products and processes, they can use this technology as a competence by coordinating the structure, system and resources of the company with technology. In addition, technological orientation is recognized as the center for launching innovative and better designed products. For this reason, it is stated that technology-oriented enterprises have to be more proactive in acquiring and implementing new technology to develop their products/services (Masa'deh et al., 2018). It is stated that technology-oriented companies should be willing to use technology as a competitive element that harmonizes their systems with each other by providing the necessary resources from outside their own equity (Jeong, Pae, \& Zhou, 2006; Srivastava, Yoo, Frankwick, \& Voss, 2013). The present study examines the effects of technology orientation on cost leadership strategy, differentiation strategy, and product innovation.

\section{Competitive Strategies}

Looking at the changes in the competitive environment surrounding the business world in recent years such as the rapid spread of new technologies and the short life span of products, firms appear to be under pressure due to the increased competition in many sectors. Companies choose to enrich their technological base as a way to increase competitive advantages in this intensely competitive environment (Jeong et al., 2006). There are two different approaches to Porter's $(1980 ; 1985)$ general competition strategies (differentiation, cost leadership). Here, the value chain required for the cost leadership strategy is different from the value chain required for the differentiation strategy. The emphasis on the differentiation strategy is to achieve superior quality and image throughout the value chain (even at high cost) while the low-cost strategy is expressed as lowering costs wherever possible. Both strategies can be successfully harmonised and used together by a business at the same time to promote higher product quality and, in this case, increas costs in a range of functional areas. Companies that follow a cost leadership strategy can mainly compete at a lower price, which they can do by reducing their costs through efficient resource/production/distribution and scale economies. In contrast, companies with differentiation strategies have to create unique products/services in order to exist in the market with higher sales prices. This is often differentiated from competitors by providing unique products with high levels of innovation capability and superior product quality (Huo, Qi, Wang, \& Zhao, 2014). The present study examined the first two general competitive strategies that Porter pointed out (i.e. differentiation and cost leadership strategies) and the impact of these strategies on the relationship between technology orientation and product innovation.

\section{Product Innovation}

The concept of innovation is seen as a strategic driving force in evaluating new opportunities and protecting information assets in a turbulent economic environment. Innovation plays a key role in providing unique products and services, creating value greater than previously realized ones and creating barriers to entry (Kim, Kumar, \& Kumar, 2012). Product 
innovation refwers to "new products/services introduced to meet the market needs". Product innovation performance demonstrates the degree to which a new product and/or service achieves market share, sales, investment return rates and profit targets (Chen, Tang, Jin, Xie, $\& \mathrm{Li}, 2014)$. Product innovation also means changing one or more features, adding new functions, or developing existing functions or means of use. Functional features refer to the ones that are suitable for the purpose; quality, reliability, durability, economic efficiency, convenience, availability and user friendliness. In financially enabled product innovation, the affordability and easy-to-finance; dynamic fee pricing, the establishment of a new production line using cheaper materials, and low-cost delivery of goods or services to the market are expected. In product innovation, it is not enough for users to have a new or improved design in terms of both emotion and visuality, but also to attract potential users, and to include features such as new information and technology more advanced than competitors' products/services. In this study, by considering the distinction between product, process and managerial innovation in the literature, we focus on product innovation, i.e. the development of new or improved products and/or services, which are particularly closely linked to the main activities of companies in general, and the successful introduction of them to the market.

\section{Technological Orientation, Cost Leadership, and Differentiation Strategies}

The pace of globalization has increased the intensity of competition and as a result firms are focused on looking for strategies that will give them a sustainable competitive advantage. These strategies often force businesses to gain cost leadership advantages over their competitors in the sector to differentiate their products and processes. The cost leadership strategy aims to reduce costs across all components of operations, resulting in above-average returns through lower prices. Technology-oriented companies have better technical skills, technology, production knowledge, and stronger bargaining power that develops with the contribution of critical resources such as special equipment (Li, 2005). A company's technology-oriented level has a significant impact on the company's innovation capability and is a source of competitive advantage that can lead to better business performance (AlAnsari, Altalib, \& Sardoh, 2013). Therefore, the following hypothesis is proposed:

H1: Technology orientation has a positive impact on the cost leadership strategy in manufacturing companies.

The differentiation strategy is one of Porter's general strategies and is closely related to innovation and performance (Zehir et al., 2015). According to Porter (1980), each general strategy is a fundamentally different approach to creating and sustaining competitive advantage, and in the differentiation strategy, a firm aims to be unique in its sector, in some dimensions highly valued by buyers. The basic principle of the differentiation strategy is to direct customer choices to their own goods and services by doing more different things than competitors do (Kurt \& Zehir, 2015). If there is a high level of technology orientation in companies, it may have a positive relationship with the differentiation strategy. Because technology orientation firms need to have more information-intensive business processes and more resources to generate new ideas, and it will be important to share and implement the 
technical information that is very useful. However, it can be said that there is a complete harmony and meaningful relationship between the objectives of technology orientation and differentiation strategy. Therefore, the second hypothesis is developed and tested:

H2: Technology orientation has a positive impact on the differentiation strategy in manufacturing companies.

\section{Technology Orientation and Product Innovation}

The related literature shows that organization's intrinsic capabilities, such as technology, marketing, $R \& D$ and culture, have a significant impact on innovation, which expresses the organization's openness to new ideas and a willingness to implement it in products and processes (Akgün, Keskin, \& Byrne, 2009). Technology capability and/or knowledge can improve product design and quality and encourage product innovation as it can prevent potential risks (Chen et al., 2014). The technology orientation of a company refers to using complex technologies in new product development, rapid integration of new technologies, proactively developing new technologies and creating new product ideas. In this way, it is possible for a company to achieve superior performance from its new products (Jeong et al., 2006). Positive relationships have been found between technology orientation and innovation process, innovation results, new product innovation and a company's exploratory innovation capability (Srivastava et al., 2013). Firms that adopt developments in technology and innovation are reporting on the assumption that completely new markets will emerge (Urban \& Heydenrych, 2015). Therefore, the thrid hypothesis is proposed:

H3: Technology orientation has a positive impact on product innovation in manufacturing companies.

\section{Competitive Strategies and Product Innovation}

With the implementation of competition strategies; there can be a positive impact on the added value created, customer satisfaction and loyalty, business performance. The differentiation strategy is one of Porter's general strategies and is closely related to innovation and performance (Porter, 1985). The differentiation strategy is about being unique in the market with unique or different products and services offered by companies. In its cost leadership strategy, a company strives hard to achieve the low-cost production and distribution to deliver lower prices than its competitors, and for many price-sensitive buyers, the cost per unit is very low (Santos-Vijande, Lopez-Sanchez, \& Trespalacios, 2012). Product innovation aims to improve the quality of a product and produce new products with different features (Birasnav, Albufalasa, \& Bader, 2013). Therefore, the fourth and fifth hypotheses are developed and tested:

H4: The cost leadership strategy has a positive impact on product innovation in manufacturing companies.

H5: The differentiation strategy has a positive impact on product innovation in manufacturing companies. 


\section{Mediation Variable Impact of Competitive Strategies on the Relationship Between Technology Orientation and Product Innovation}

The examination of pertinent literature indicates that there are studies that have direct or indirect relationship between technology orientation and product and service innovation (Chen et al., 2014; Jeong et al., 2006; Srivastava et al., 2013). The cost leadership and differentiation strategies of Porter $(1980,1985)$ provide a very important opportunity for companies to innovate products and services. The main purpose of technology-oriented companies in particular is to produce quality, different functional features and user-friendly products that will be more attractive to customers at a lower cost than similar products in the market. However, it is not easy to achieve both cost leadership and differentiated and new products at the same time. Therefore, it is expected that the appropriate implementation of differentiation and cost leadership strategies can improve the product and service innovation performance of technology-oriented companies. Therefore, the six and seven hypotheses are expressed as;

H6: The cost leadership strategy has a mediation variable effect on the relationship between technology orientation and product innovation in manufacturing companies

H7: Differentiation strategy has a mediation variable effect on the relationship between technology orientation and product innovation in manufacturing companies

\section{Method}

In this study, 383 white collar (engineer) employees were surveyed. Using SPSS 25 and AMOS Program, the factor analysis (explanatory and confirmatory) and reliability analysis were performed for the items with 5-point Likert scale, and then correlation analysis, regression analysis, sobel test and Hayes process were used for the analysis of the effect of the mediator variable. In particular, 238 male and 145 female engineers working in different departments of 12 companies producing parts for white goods companies answered the survey in accordance with the criteria. Almost, $35 \%$ of the participants were in the 17-27 age group, $45 \%$ were in the $28-40$ age group, and $20 \%$ were over the age of 41 . In total, $85 \%$ of the respondents were university graduates, $12 \%$ had master's degree and 3\% had doctorate degree. The survey consists of scales related to Technology Orientation, Cost Leadership Strategy, Differentiation Strategy and Product Innovation. Technology Orientation scale was adopted from the studies of Avolio, Bass, and Jung (1999), Al-Ansari, Altalib, and Sardoh (2013) and Masa'deh, Al-Henzab, Tarhini, and Obeidat (2018). The scale developed by Bass and Avolio (2000) was used to measure the Cost Leadership Strategy. The Differentiation Strategy scale adopted from the work of Kohli and Jaworski (1990), Lynch, Keller, and ve Ozment (2000), Dess and Davies (1984), Porter (1980). Tiwana's (2004) scale was used to measure Product Innovation.

\section{Research Goal}

This research aims to determine the effects of the relationships between variable effect and product innovation. The reason for the selection of companies producing parts for companies in the white goods sector is that product innovation activities take place intensively within 
this sector due to technological developments. The reason for choosing the sample audience from white-collar engineers is because they are involved in both product innovation and technology Orientation. Therefore, our research objective is to evaluate and analyze companies' production both in terms of technology orientation and innovation.

\section{Research Framework}

Based on literature review, the research adopts a quantitative approach and the analysis of the data is based on statistical concepts. Figure 1 presents the research model.

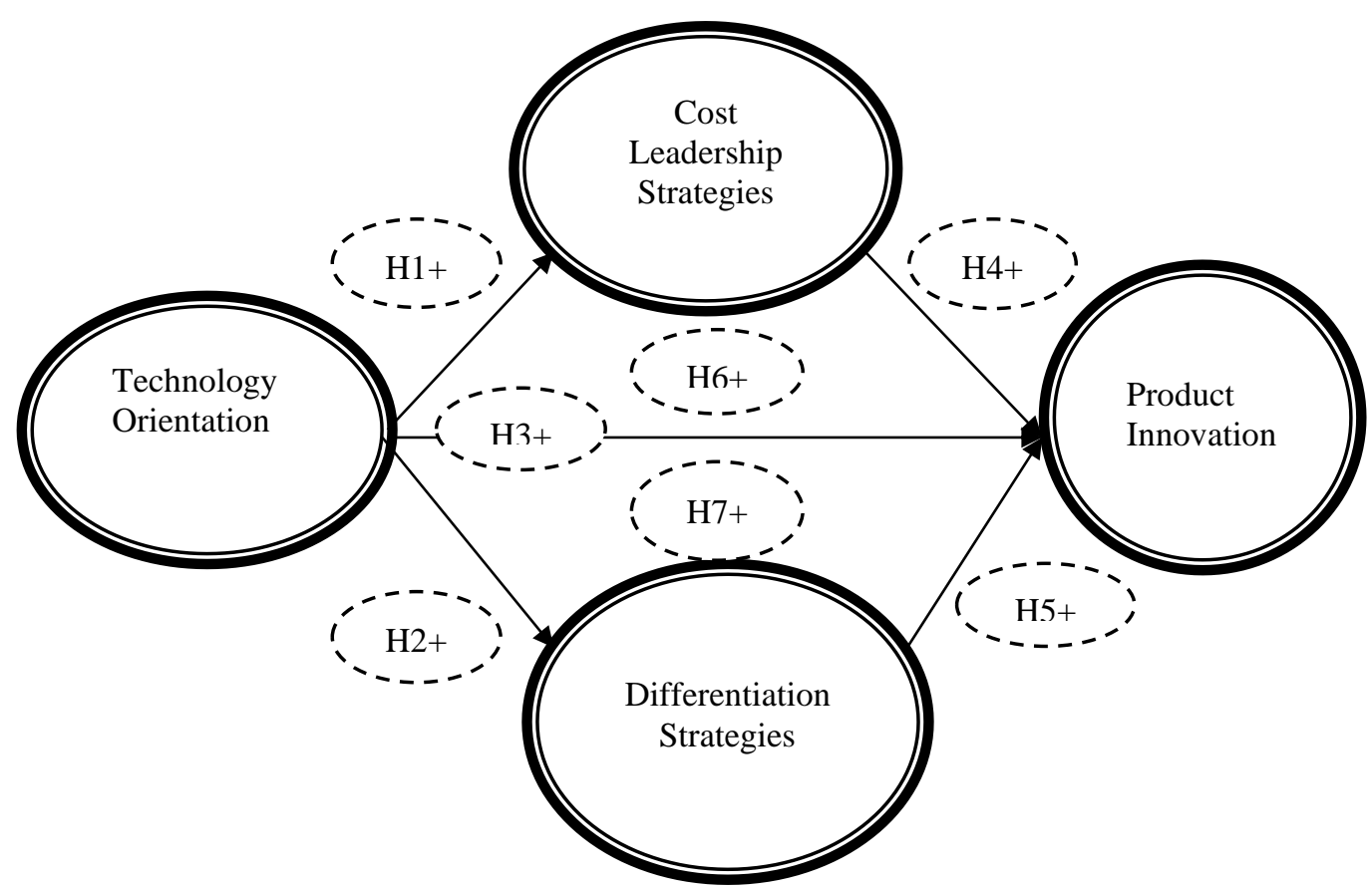

Figure 1. Research model

\section{Analysis}

Factor analysis was conducted to investigate the construct validity of the scale. The KaiserMeyer-Olkin sample eligibility value is .92 and Bartlett's globality test has a level of significance of 0.000 (for $p \leq .05$ ), indicating that the data is suitable for factor analysis (Büyüköztürk, 2005). In this study, variables were prepared according to the 5-point Likert scale and measured with a 35-item questionnaire. As a result of factor analysis, 14 items were excluded from the scale as they decreased to different factors by decreasing reliability. The remaining 21 items were divided into four factors. As a result of the analysis of the basic components that can be analyzed by factor analysis, four factors were formed. The results are shown in Table 1: 
Table 1

Rotated Component Matrix ${ }^{a}$

\begin{tabular}{|c|c|c|c|c|}
\hline \multicolumn{5}{|l|}{ Rotated Component Matrix ${ }^{\mathrm{a}}$} \\
\hline & \multicolumn{4}{|c|}{ Component } \\
\hline & 1 & 2 & 3 & 4 \\
\hline FS12. New business and market opportunities are exploited. & .78 & & & \\
\hline FS11. We are constantly improving our existing products in the market. & .77 & & & \\
\hline FS14. We are expanding our production line to produce different products. & .76 & & & \\
\hline FS13. We respond to different customer needs in different markets. & .72 & & & \\
\hline FS9. We develop additional models and dimensions on our existing products. & .70 & & & \\
\hline FS2. We offer products for the specific needs of our customers. & .67 & & & \\
\hline FS1. We are developing new products or services better than our competitors. & .63 & & & \\
\hline FS10. We are very fast in the time of developing new products and launching them. & .61 & & & \\
\hline MLS5. We minimize marketing costs. & & .84 & & \\
\hline MLS6. We are minimizing inert production capacity. & & .80 & & \\
\hline MLS4. We minimize purchasing costs (raw materials, etc.). & & .79 & & \\
\hline MLS7. We are minimizing costs such as waste maintenance repairs and so on. & & .74 & & \\
\hline MLS3. We are strictly subject to cost control for all our activities. & & .69 & & \\
\hline MLS8. We maximize efficiency in all units and activities. & & .63 & & \\
\hline TO3. We always use the latest technologies in new products/services. & & & .78 & \\
\hline TO4. We can easily apply technological innovations in our company. & & & .77 & \\
\hline $\begin{array}{l}\text { TO1. Technological innovation in our company is easily accepted in program/project } \\
\text { management. }\end{array}$ & & & .77 & \\
\hline $\begin{array}{l}\text { TO2. Our company uses advanced technologies in the process of developing new } \\
\text { products/services. }\end{array}$ & & & .75 & \\
\hline $\begin{array}{l}\text { UY1. Every year we promote more products/services than competitors in the target market } \\
\text { audience that is important to us on average. }\end{array}$ & & & & .84 \\
\hline $\begin{array}{l}\text { UY2. Industry experts say we are more productive in promoting new products/services in the } \\
\text { target market. }\end{array}$ & & & & .81 \\
\hline $\begin{array}{l}\text { UY3. It is not possible for our competitors to keep up with our pace of new product/service } \\
\text { promotion in our target markets. }\end{array}$ & & & & .80 \\
\hline
\end{tabular}

Note: TO: Technology Orientation, MLS: Cost Leadership Strategy, FS: Differentiation Strategy, UY: Product Innovation

\section{Confirmatory Factor Analysis}

In the confirmatory factor analysis, it can be explained that if the values measured for the model fit certain criteria, the scales define the variables and further analysis can be continued (Harrington, 2009). As shown in Figure 2, the analysis indicated values for model fit as: $\mathrm{X} 2 / \mathrm{df}=3.10<5, .85<\mathrm{GFI}=.89, .90<\mathrm{IFI}=.94, .90<\mathrm{NFI}=.95, .90<\mathrm{CFI}=.920$, RMSEA $=.06<.08$. Looking at the results, it can be seen that there is harmony in the scales specified in the descriptive factor analysis. Since all 4 variables have been validated, the reliability, correlation and regression analyses can be performed. 


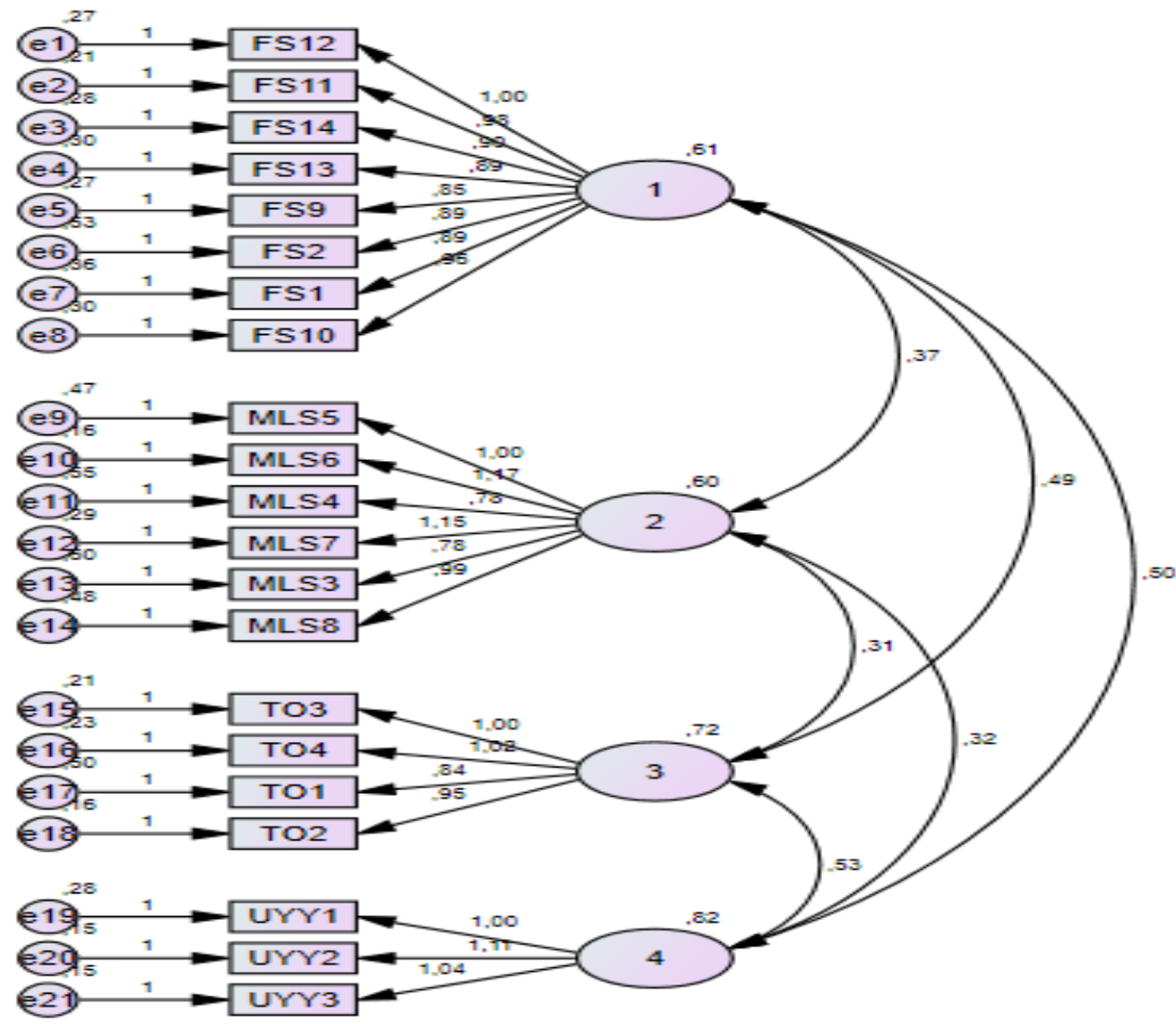

Note: TO: Technology Orientation, MLS: Cost Leadership Strategy, FS: Differentiation Strategy, UY: Product Innovation

Figure 2. Confirmatory factor analysis

According to İslamoğlu and Alniaçik (2013), in social sciences, the value of cronbach alpha coefficient of .60 or higher is considered sufficient for the research to be reliable; therefore, as represented in Table 2, it can be said that the results of the study are reliable. At the same time, Nunnally and Bernstein's (1978) Cronbach's alpha coefficient of .50 and above is considered sufficient in the literature (Hair, Bush, \& Ortinau, 2000; Nunnally \& Bernstein, 1978). However, the general opinion in business-management sciences is that .70 and above are appropriate.

Table 2

Reliability Analysis

\begin{tabular}{lcc}
\hline Variables & Number of Questions & Cronbach Alfa $(\alpha)$ Values \\
\hline Technology Orientation & 4 & .90 \\
Cost Leadership Strategy & 6 & .89 \\
Differentiation Strategy & 8 & .92 \\
Product Innovation & 3 & .93 \\
\hline
\end{tabular}

The correlation coefficient is expressed with the letter " $\mathrm{r}$ " and is valued between -1 and $+1(-1 \leq \mathrm{r} \leq+1)$. If the correlation coefficient is -1 there is a full negative linear relationship. Thus, when one variable increases, the other decreases, on the contrary, if one variable decreases, the other increases. If the correlation coefficient is +1 , there is a complete positive linear relationship. Therefore, when one variable increases, the other increases, if one 
variable decreases, the other decreases. If the correlation coefficient is " 0 ", there is no relationship between the two variables (Kalayc1, 2010). In this study, since correlation analysis was performed between continuous variables, Pearson correlation coefficient was taken into consideration. As a result of correlation analysis presented in Table 3, we can explain that the relationships between variables are positive and meaningful. The positive relationship between variables indicates that the power of interaction between variables is positive.

Table 3

Correlations Coefficient between Variables

\begin{tabular}{|c|c|c|c|c|c|}
\hline \multicolumn{6}{|c|}{ Correlations } \\
\hline & & $\begin{array}{c}\text { Differentiation } \\
\text { Strategy }\end{array}$ & $\begin{array}{c}\text { Cost Leadership } \\
\text { Strategy }\end{array}$ & $\begin{array}{l}\text { Technology } \\
\text { Orientation }\end{array}$ & $\begin{array}{c}\text { Product } \\
\text { Innovation }\end{array}$ \\
\hline \multirow[t]{3}{*}{ Differentiation Strategy } & \begin{tabular}{|l|} 
Pearson Correlation \\
\end{tabular} & 1 & $.57^{* *}$ & $.68^{* *}$ & $.65^{* *}$ \\
\hline & Sig. (2-tailed) & & .000 & .000 & .000 \\
\hline & $\mathrm{N}$ & 383 & 383 & 383 & 383 \\
\hline \multirow[t]{3}{*}{ Cost Leadership Strategy } & Pearson Correlation & $.57^{* *}$ & 1 & $.42^{* *}$ & $.43^{* *}$ \\
\hline & Sig. (2-tailed) & .000 & & .000 & .000 \\
\hline & $\mathrm{N}$ & 383 & 383 & 383 & 383 \\
\hline \multirow{3}{*}{$\begin{array}{l}\text { Technology } \\
\text { Orientation }\end{array}$} & Pearson Correlation & $.68^{* *}$ & $.42^{* *}$ & 1 & $.62^{* *}$ \\
\hline & \begin{tabular}{|l} 
Sig. (2-tailed) \\
\end{tabular} & .000 & .000 & & .000 \\
\hline & $\mathrm{N}$ & 383 & 383 & 383 & 383 \\
\hline \multirow[t]{3}{*}{ Product Innovation } & Pearson Correlation & $.65^{* *}$ & $.43^{* *}$ & $.62^{* *}$ & 1 \\
\hline & Sig. (2-tailed) & .000 & .000 & .000 & \\
\hline & $\mathrm{N}$ & 383 & 383 & 383 & 383 \\
\hline
\end{tabular}

Regression analysis was used to analyze the effect of arguments (IV) on dependent variables (DV). According to the results of regression analyses presented, 5 hypotheses were accepted outside the agent variable (MV) effect (See Table 4 and Table 5). Looking at the results of regression analysis of hypotheses tested outside of the mediation variable effect, we can explain that there is a positive and meaningful effect. This also demonstrates the importance of technology orientation, cost leadership and differentiation strategy for companies in the manufacturing sector.

Table 4

Regression Analysis Results

\begin{tabular}{|c|c|c|c|c|c|}
\hline IV & DV & Standard $\beta$ & Sig. & $\begin{array}{l}\text { Adjusted R } \\
\text { Square }\end{array}$ & F Value \\
\hline Technology Orientation & Cost Leadership Strategy & .42 & $.000 * * *$ & .17 & 124.90 \\
\hline Technology Orientation & Differentiation Strategy & .68 & $.000 * * *$ & .46 & 497.38 \\
\hline Technology Orientation & Product Innovation & .62 & $.000 * * *$ & .39 & 367.71 \\
\hline Cost Leadership Strategy & Product Innovation & .43 & $.000 * * *$ & .19 & 135.04 \\
\hline Differentiation Strategy & Product Innovation & .65 & $.000 * * *$ & .42 & 421.77 \\
\hline
\end{tabular}


Table 5

Results of Hypotheses Developed and Tested

\begin{tabular}{|c|c|c|}
\hline Hypotheses & $\begin{array}{l}\text { Supported/Not } \\
\text { Supported }\end{array}$ & $\begin{array}{l}\text { Significance Level } \\
\text { (Sig.) }\end{array}$ \\
\hline $\begin{array}{l}\mathbf{H}_{1} \text { : Technology orientation has a positive impact on the cost leadership strategy in } \\
\text { manufacturing companies }\end{array}$ & Supported & $p<.001$ \\
\hline $\begin{array}{l}\mathbf{H}_{2} \text { : Technology orientation has a positive impact on the differentiation strategy in } \\
\text { manufacturing companies }\end{array}$ & Supported & $p<.001$ \\
\hline $\begin{array}{l}\mathbf{H}_{3} \text { : Technology orientation has a positive impact on product innovation in manufacturing } \\
\text { companies }\end{array}$ & Supported & $p<.001$ \\
\hline $\begin{array}{l}\mathbf{H}_{4} \text { : The cost leadership strategy has a positive impact on product innovation in } \\
\text { manufacturing companies }\end{array}$ & Supported & $p<.001$ \\
\hline $\begin{array}{l}\mathbf{H}_{5} \text { : The differentiation strategy has a positive impact on product innovation in } \\
\text { manufacturing companies }\end{array}$ & Supported & $p<.001$ \\
\hline
\end{tabular}

\section{Determination of the Mediation Variable Effect}

In determining the effect of the mediating variable in the research model, in particular, the cost leadership strategy and the differentiating strategy were influenced by the relationship between the technology orientation variable and the product innovation dependent variable. This effect is shown Table 6.

Table 6

The Effect of the Mediation Variable (MV)

\begin{tabular}{|c|c|c|c|c|c|c|}
\hline & IV & DV & Standard $\beta$ & Sig. & $\begin{array}{l}\text { Adjusted R } \\
\text { Square }\end{array}$ & F Value \\
\hline \multirow[b]{2}{*}{ Regression } & $\begin{array}{c}\text { Technology Orientation } \\
\text { (IV) }\end{array}$ & \multirow[b]{2}{*}{$\begin{array}{l}\text { Product } \\
\text { Innovation } \\
\text { (DV) }\end{array}$} & .53 & $.000^{* * * *}$ & .39 & 367.71 \\
\hline & $\begin{array}{l}\text { Cost Leadership } \\
\text { Strategy (MV) }\end{array}$ & & .21 & $.000^{* * * *}$ & .42 & 213.12 \\
\hline \multirow[b]{2}{*}{ Regression } & $\begin{array}{c}\text { Technology Orientation } \\
\text { (IV) }\end{array}$ & \multirow[b]{2}{*}{$\begin{array}{l}\text { Product } \\
\text { Innovation } \\
\text { (DV) }\end{array}$} & .33 & $.000^{* * * *}$ & .39 & 367.71 \\
\hline & $\begin{array}{c}\text { Differentiation Strategy } \\
\text { (MV) }\end{array}$ & & .42 & $.000 * * *$ & .48 & 269.73 \\
\hline
\end{tabular}

\section{Measurement of Mediator Variable Effect with Sobel Test}

Sobel test (Sobel, 1982) is calculated using standard error values and uncorrected regression coefficients of related variables. MacKinnon, Warsi, and Dwyer (1995) have expanded statistical-based methods in which the variable effect can be officially assessed. There are two main versions of the Sobel test that is Aroian (1947), (popularized by Baron \& Kenny, 1986, as the Sobel test) and Goodman (1960). 
Table 7

The Results of Sobel Test for Measuring Mediation Effect

The analysis of the mediation variable effect of the cost leadership strategy in the relationship between technology orientation and product innovation in manufacturing companies by sobel test:

\begin{tabular}{|c|c|c|c|c|c|c|}
\hline Variables & & Input: & & Test statistic: & Std. Error: & p-value: \\
\hline IV & $\mathrm{a}$ & .33 & Sobel test: & 4.84 & .01 & .000 \\
\hline \multirow[t]{2}{*}{ MV } & $\mathrm{b}$ & .25 & Aroian test: & 4.82 & .01 & .000 \\
\hline & $\mathrm{Sa}$ & .03 & Goodman test: & 4.86 & .01 & .000 \\
\hline DV & $\mathrm{Sb}$ & .04 & & & & \\
\hline
\end{tabular}

If the $\mathrm{p}$ value is less than $<.05$, we can explain the mediator variable effect. Since the P-value value is less than .05, we can accept the mediation variable effect.

The analysis of the mediation variable effect of the differentiation strategy in the relationship between technology orientation and product innovation in manufacturing companies by sobel test:

\begin{tabular}{|l|c|c|c|c|c|c|}
\hline Variables & & Input: & & Test statistic: & Std. Error: & p-value: \\
\hline IV & & $\mathrm{a}$ & 0.338 & Sobel test: & 4.35 & .02 \\
\hline $\mathrm{MV}$ & & $\mathrm{b}$ & 0.292 & Aroian test: & 4.33 & .000 \\
\cline { 2 - 7 } & $\mathrm{Sa}$ & 0.037 & Goodman test: & 4.37 & .000 \\
\hline DV & $\mathrm{Sb}$ & 0.059 & & & .000 \\
\hline $\begin{array}{l}\text { If the p value is less than < .05, we can explain the mediator variable effect. Since the P-value value is less than .05, we can accept the } \\
\text { mediation variable effect. }\end{array}$
\end{tabular}

Hayes process analysis was performed on the mediator variable effect and according to each hypothesis. According to the Hayes process analysis results presenr, the mediation variable effect can be accepted because there is no "0" value between BootLLCI and BootULCI. Therefore, the cost leadership strategy has a mediation variable effect. Furthemore, the differentiation strategy has a mediation variable effect. The results of hayes process analysis are displayed in Table 8 and Table 9 below:

Table 8

The Results of Hayes Process Analysis Mediation Variable Effect of the Cost Leadership Strategy

The analysis of the mediation variable effect of the cost leadership strategy in the relationship between technology orientation and product innovation in manufacturing companies by hayes process analysis:

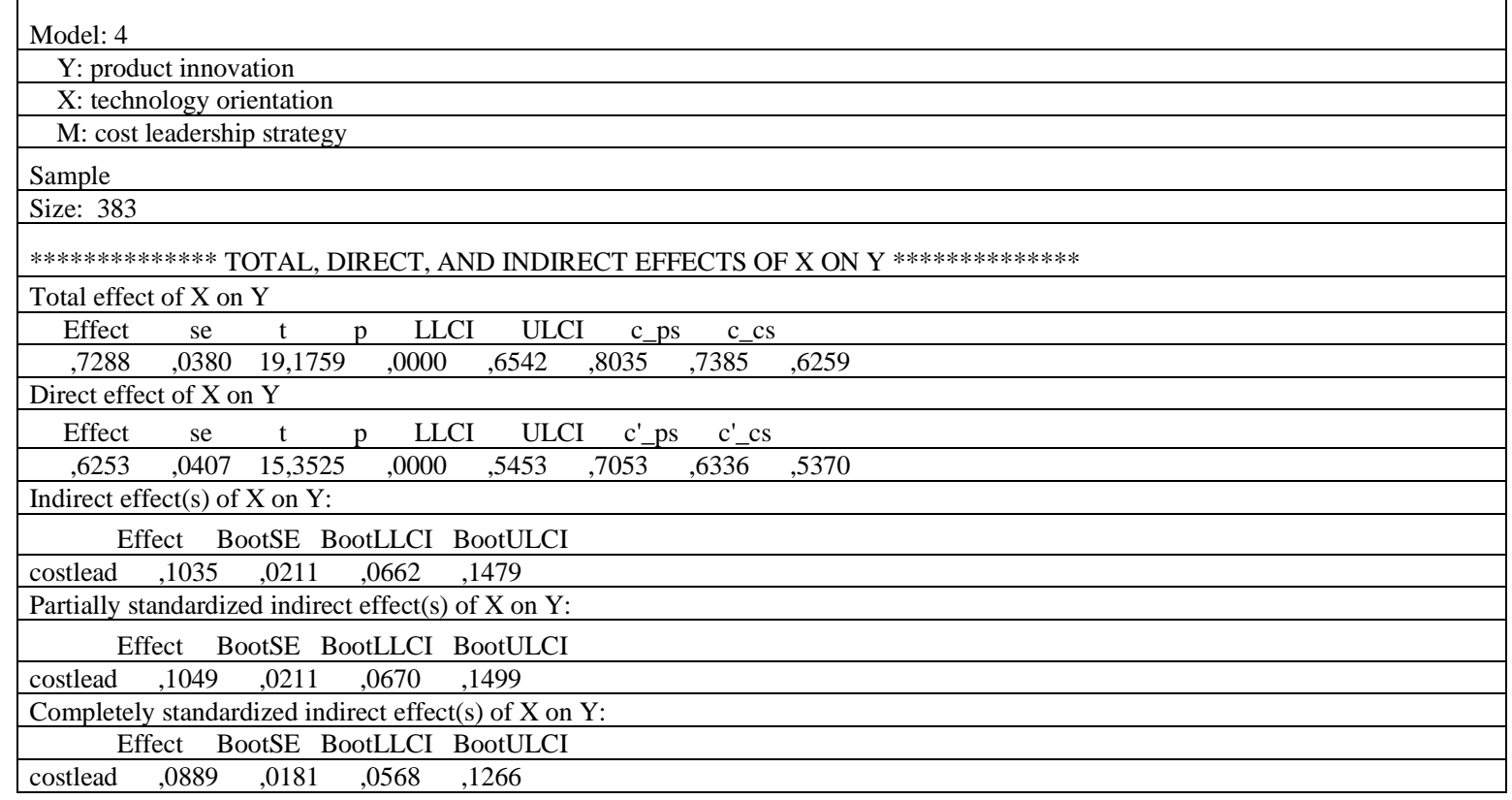


Table 9

The Results of Hayes Process Analysis Mediation Variable Effect of the Differentiation Strategy

The analysis of the mediation variable effect of the differentiation strategy in the relationship between technology orientation and product innovation in manufacturing companies by hayes process analysis:

Model: 4

Y: product innovation
X: technology orientation
M: differentiation strategy

Sample

Size: 383

的************** TOTAL, DIRECT, AND INDIRECT EFFECTS OF X ON Y $* * * * * * * * * * * * * *$

Total effect of $\mathrm{X}$ on $\mathrm{Y}$

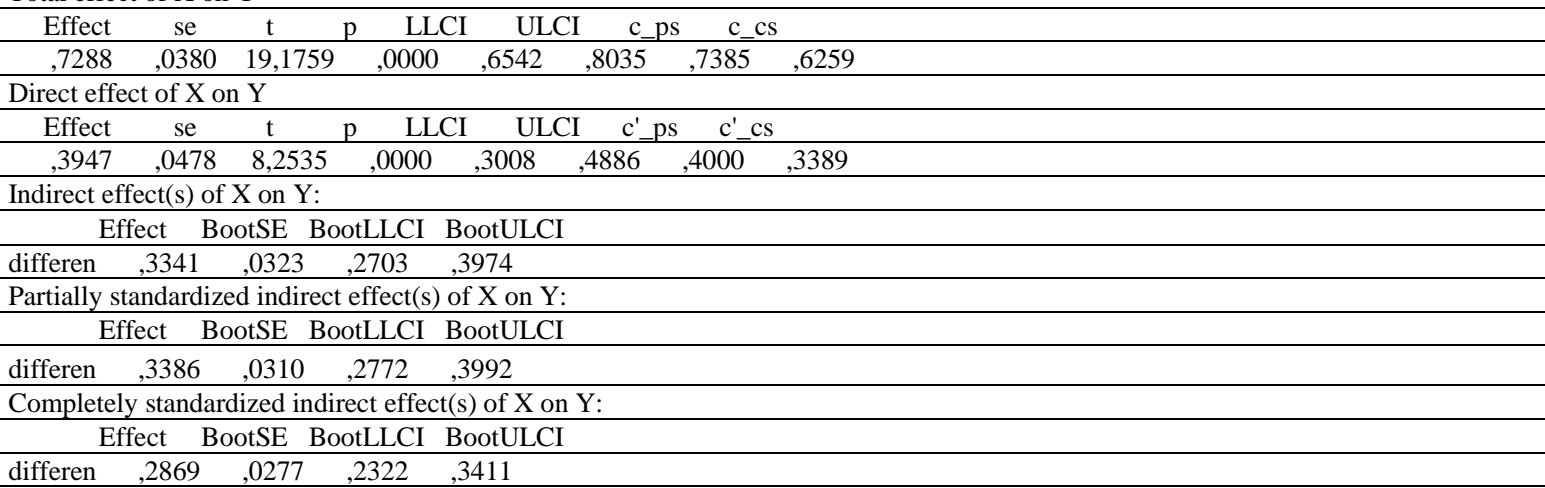

In the research model in which the cost leadership strategy and differentiation strategy tool variable effect was measured, the $\mathrm{H}_{6}$ and $\mathrm{H}_{7}$ hypotheses were found to have effects on the relationship between the cost leadership strategy and differentiation strategy tool variable and technology orientation and product innovation. Table 10 shows the Hypothesis results.

Table 10

Results of the Hypotheses

\begin{tabular}{llc}
\hline Hypotheses & $\begin{array}{c}\text { Supported / Not } \\
\text { Supported }\end{array}$ & $\begin{array}{c}\text { Significance Level } \\
\text { (Sig.) }\end{array}$ \\
\hline $\begin{array}{l}\mathbf{H}_{\mathbf{6}} \text { : The cost leadership strategy has a mediation variable effect on the relationship } \\
\text { between technology orientation and product innovation in manufacturing companies }\end{array}$ & Supported \\
& \\
$\begin{array}{l}\mathbf{H}_{7} \text { : Differentiation strategy has a mediation variable effect on the relationship } \\
\text { between technology orientation and product innovation in manufacturing companies }\end{array}$ & Supported & $p<.001$ \\
\hline
\end{tabular}

\section{Discussion}

This study examined the relationship between technology orientation, cost leadership and differentiation strategies and product innovation. According to the results of the analysis, there is a statistically positive and meaningful relationship between technology orientation and cost leadership and differentiation strategies. These results are in line with the findings of the studies found in the literature (Al-Ansari et al., 2013; Prajogo, 2007; Zehir et al., 2015). At the same time, technology orientation has a statistically positive and meaningful relationship with product innovation. Therefore, the $\mathrm{H} 3$ hypothesis is supported. This result is in parallel with the findings of Chen et al. (2014), Srivastava et al. (2013), and Hortinha, Lages, and Lages (2011). According to the results of regression analysis, it was determined that there is a statistically positive and meaningful relationship between cost leadership and differentiation strategies and product innovation. Accordingly, $\mathrm{H}_{4}$ and $\mathrm{H}_{5}$ hypotheses are supported. These results are consistent with the results of Santos-Vijande et al. (2012), Zehir et al. (2015), and Huo et al. (2014). Today, businesses have to develop new products, services and processes in order to cope with their competitors and gain a competitive 
advantage in a global environment. From this point of view, innovation is the most critical success factor, especially for entrepreneurial businesses. Thompson (1965) referes to the innovation as the discovery, development and implementation of new ideas, processes, products or services. In defining the innovation, Zaltman, Duncan, and Holbek (1973) and Tidd, Bessant, and Pavit (1997) point out to opportunities as a process of transforming opportunities into new ideas and putting them into practice (Oflazoğlu, 2010). In the latest edition of the OSLO handbook (OECD, 2018), which is considered the main reference in innovation, innovation is a printout; the process made available by the product or business unit offered to potential users, and is defined as a new or improved product or process that differs significantly from the previous products or processes of a business unit. Finally, according to the results of regression analysis, cost leadership and differentiation strategies mediate the impact on technology orientation and product innovation. For this reason, $\mathrm{H}_{6}$ and $\mathrm{H}_{7}$ hypotheses are also supported.

The mediation effect of differentiation and cost leadership strategies in the relationship between technology orientation and product innovation has been studied for the first time in this research. The study focused on companies in the medium and large-scale production sector operating in Turkey and the findings may not be generalized to other organizations. Therefore, more research is proposed for generalization of findings by small companies in different countries or different production companies in Turkey and other countries. Another constraint of this survey is that items about technology orientation, differentiation and cost leadership strategies and product innovation are answered by white collar employees and middle or senior managers of firms. Items can be filled by different participants to avoid the same resource bias in future research. Researchers who will work on this subject are advised to investigate the relationships between focus strategy and process innovation that are not addressed.

\section{Conclusion and Suggestions}

In this srudy, technology orientation shows that competitive strategies have a positive effect on firms' competitive advantage by producing innovative products and services in the sector in which they are active. The significant results have been reached in terms of understanding that technology orientation and competitive strategies affect company product innovation. First, the findings of technology orientation in positive and meaningful relationships with both competitive strategies and product innovation have important implications for managers and sectoral practitioners. Technology orientation primarily with cost leadership and differentiation strategies and their positive and meaningful relationships will give companies better technical skills, technology, production knowledge, special equipment and stronger bargaining power $(\mathrm{Li}, 2005)$. The results are in line with other studies that have found positive relationship between technology orientation and product innovation. Companies that want to exist with sustainable profitability in a competitive sector are more important to technological orientation they may be able to stay one step ahead of their competitors in the production of new and unique products (Masa'deh, 2017; Chen et al., 2014). Business units need to focus more on developing technology than the demands of the market; thereby they need to develop more innovative and technologically superior products than products offered by competitors, they can thus be a profitability leader. Know-how at the heart of 
technological superiority has become an easily retrievable value with engineering, copying, purchasing, production and process optimization, etc. In this respect, it is obvious that product innovation cannot be sufficient to maintain sustainable profitability and market leadership without the technology orientation. At this point, technology orientation makes it possible to investigate the feasibility of using the cost leadership and differentiation strategies at the same time separately or together in order for a firm to maintain its product innovation capability in the market. It is observed that both of the competitive strategies discussed in this study have a positive and meaningful relationship with product innovation. Santos-Vijande et al. (2012) stated that the cost leadership strategy is based on the lowest production and distribution costs that provide lower prices than its competitors. Porter (1991) emphasized the differentiation strategy in offering superior quality and high customer value. It is understood that it can be possible to catch, improve product quality and produce new and unique products with different characteristics (Birasnav, 2013). The existence of a mediator effect in the relationship between technology orientation and product innovation confirms the opinion that the efforts of companies investing in technology and trying to exist with technological orientation in the market will be significantly affected if the cost leadership and differentiation strategies are applied separately or together. In this sense, it will be possible for companies to reach their strategic goals more effectively and efficiently if they act in accordance with cost leadership and differentiation strategies based on the priority of the market and customer needs, not only from a technological point of view, but also based on the product innovation.

\section{References}

Akgün, A. E., Keskin, H., \& Byrne, J. (2009). Organizational emotional capability, product and process innovation, and firm performance: An empirical analysis. Journal of Engineering and Technology Management, 26(3), 103-130.

Al-Ansari, Y., Altalib, M., \& Sardoh, M. (2013). Technology orientation, innovation and business performance: A study of Dubai SMEs. The International Technology Management Review, 3(1), 1-11.

Aroian, L. A. (1947). The probability function of the product of two normally distributed variables. Annals of Mathematical Statistics, 18, 265-271.

Avolio, B. J., Bass, B. M., \& Jung, D. I. (1999). Re-examining the components of transformational and transactional leadershipusing the multifactor leadership questionnaire. Journal of Occupational and Organizational Psychology, 72(4), 441-463.

Baron, R. M., \& Kenny, D. A. (1986). The moderator-mediator variable distinction in social psychological research: Conceptual, strategic, and statistical considerations. Journal of Personality and Social Psychology, 51, 1173-1182.

Bass, B. M., \& Avolio, B. J. (2000). MLQ, multifactor leadership questionnaire sampler set: Technical report, leader form, rater form, and scoring key for MLQ form $5 x$-short. USA: Mind Garden.

Birasnav, M., Albufalasa, M., \& Bader, Y. (2013). The role of transformational leadership and knowledge management processes on predicting product and process innovation: An empirical study developed in Kingdom of Bahrain. Tékhne, $11(2), 64-75$.

Bulut Ç., Alpkan, L., \& Yılmaz, C. (2009). Stratejik oryantasyonlar ve firma performansı ilişkisi: Literatür gelişimi üzerine kavramsal bir çalışma [Relationship between strategic orientations and firm performance: A conceptual study on the development of the literature]. Dokuz Eylül Üniversitesi İ̧letme Fakültesi Dergisi, 10(1), 1-34.

Büyüköztürk, Ş. (2005). Handbook of data analysis for social sciences. Ankara: PegemA. 
Chen, Y., Tang, G., Jin, J., Xie, Q., \& Li, J. (2014). CEO s' transformational leadership and product innovation performance: The roles of corporate entrepreneurship and technology orientation. Journal of Product Innovation Management, 31, 2-17.

Dess, G. G., \& Davis, P. S. (1984). Porter's (1980) generic strategies as determinants of strategic group membership and organizational performance. Academy of Management journal, 27(3), 467-488.

Goodman, L. A. (1960). On the exact variance of products. Journal of the American Statistical Association, 55, $708-713$.

Hair, J. F., Bush, R. P., \& Ortinau, D. J. (2000). Marketing research: A practical approach for the new millennium. Irwin Professional Publishing.

Harrington, D. (2009). Confirmatory factor analysis. Oxford university press.

Hortinha, P., Lages, C., \& Lages, L. F. (2011). The trade-off between customer and technology orientations: impact on innovation capabilities and export performance. Journal of International Marketing, 19(3), 36-58.

Huo, B., Qi, Y., Wang, Z., \& Zhao, X. (2014). The impact of supply chain integration on firm performance: The moderating role of competitive strategy. Supply Chain Management: An International Journal, 19(4), 369-384.

İslamoğlu, A. H., \& Alniaçik, Ü. (2013). Sosyal bilimlerde araştırma yöntemleri, geliştirilmiş ve gözden geçirilmiş 3 . Baskl [Research methods in social sciences, developed and revised 3rd Edition]. İstanbul: Beta Yayınevi.

Jeong, I., Pae, J. H., \& Zhou, D. (2006). Antecedents and consequences of the strategic orientations in new product development: The case of Chinese manufacturers. Industrial Marketing Management, 35(3), 348-358.

Kalayc1, Ş. (2010). SPSS uygulamalı çok değişkenli istatistik teknikleri (Vol. 5) [SPSS applied multivariate statistics techniques]. Ankara, Turkey: Asil Yayın Dağıtım.

Kim, D. Y., Kumar, V., \& Kumar, U. (2012). Relationship between quality management practices and innovation. Journal of Operations Management, 30(4), 295-315.

Kohli, A. K., \& ve Jaworski, B. J. (1990). Market orientation: The construct, research propositions, and managerial implications. Journal of Marketing, 54(2), 1-18.

Kurt, A., \& Zehir, C. (2016). The relationship between cost leadership strategy, total quality management applications and financial performance. Doğuş Üniversitesi Dergisi, 17(1), 97-110.

Li, J. J. (2005). The formation of managerial networks of foreign firms in China: The effects of strategic orientations. Asia Pacific Journal of Management, 22(4), 423-443.

Lynch, D. F., Keller, S. B. ve Ozment, J. (2000). The effects of logistics capabilities and strategy on firm performance. Journal of Business Logistics, 21(2), 47-67.

MacKinnon, D. P., Warsi, G., \& Dwyer, J. H. (1995). A simulation study of mediated effect measures. Multivariate Behavioral Research, 30, 41-62.

Masa'deh, R. E., Al-Henzab, J., Tarhini, A., \& Obeidat, B. Y. (2018). The associations among market orientation, technology orientation, entrepreneurial orientation and organizational performance. Benchmarking: An International Journal, 25(8), 3117-3142.

Nunnally, J., \& Bernstein, I. H. (1978). Psychometric theory. New York, NY: Edmcgraw-hill.

OECD, Manual, O. O. (2018). Guidelines for collecting, reporting and using data on innovation.

Oflazoğlu, S. (2010). İşletmelerin stratejik yönlülükleri ile yenilik ve performans üzerindeki etkileri [Strategic directives of businesses and their effects on innovation and performance]. (Unpublished doctoral dissertation). Ankara Ünv, Sosyal Bilimleri Enstitüsü, İşletme Ana Bilim Dalı.

Porter, M. (1980). Competitive strategy. New York: Free Press.

Porter, M. (1985). Competitive advantage. New York: Free Press.

Porter, M. E. (1991). Towards a dynamic theory of strategy. Strategic Management Journal, 12(S2), 95-117.

Prajogo, D. I. (2007). The relationship between competitive strategies and product quality. Industrial management and data systems, 107(1), 69-83.

Santos-Vijande, M. L., Lopez-Sanchez, J. A., \& Trespalacios, J. A. (2012). How organizational learning affects a firm's flexibility, competitive strategy, and performance. Journal of Business Research, 65(8), 1079-1089.

Sobel, M. E. (1982). Asymptotic intervals for indirect effects in structural equations models. In S. Leinhart (Ed.), Sociological methodology (pp. 290-312). San Francisco: Jossey-Bass.

Srivastava, P., Yoo, J., Frankwick, G. L., \& Voss, K. E. (2013). Evaluating the relationship of firm strategic orientations and new product development program performance. Journal of Marketing Theory and Practice, 21(4), 429-440.

Thompson, V. A. (1965). Bureaucracy and innovation. Administrative Science Quarterly, 1-20. 
Tidd, J., Bessant, J., \& Pavit, K. (1997). Managing innovation: Integrating technological, market, and organizational change. Chichester: John Wiley and Sons.

Tiwana, A. (2004). An empirical study of the effect of knowledge integration on software development performance. Information and Software Technology, 46(13), 899-906.

Urban, B., \& Heydenrych, J. (2015). Technology orientation and effectuation-links to firm performance in the renewable energy sector of South Africa. South African Journal of Industrial Engineering, 26(3), 125-136.

Williams, F. P., D'Souza, D. E., Rosenfeldt, M. E., \& Kassaee, M. (1995). Manufacturing strategy, business strategy and firm performance in a mature industry. Journal of Operations Management, 13(1), 19-33.

Zaltman, G., Duncan, R., \& Holbek, J. (1973). Innovations and organizations. United States: John Wiley \& Sons.

Zehir, C., Can, E., \& Karaboga, T. (2015). Linking entrepreneurial orientation to firm performance: the role of differentiation strategy and innovation performance. Procedia-Social and Behavioral Sciences, 210, 358-367.

Zhou, K. Z., Yim, C. K., \& Tse, D. K. (2005). The effects of strategic orientations on technology-and market-based breakthrough innovations. Journal of Marketing, 69(2), 42-60. 